\title{
Design and Experimental Investigation of a Novel Solar Collector with a W-Shape Cover
}

\author{
${ }^{1,2}$ Edoun Marcel, ${ }^{2}$ Djimasra Bonheur, ${ }^{2}$ Kuitche Alexis and ${ }^{3}$ Zeghmati Belkacem \\ ${ }^{1}$ The U.I.T, P.O. Box 455 University of Ngaoundere, Cameroon \\ ${ }^{2}$ Laboratory of Energetic and Applied Thermal Process, ENSAI, P.O. Box 455 University of Ngaoundere, Cameroon \\ ${ }^{3}$ Laboratory of Mathematics and Physics, University of Perpignan-Via Domitia, France
}

\author{
Article history \\ Received: $12-07-2019$ \\ Revised: 04-09-2019 \\ Accepted: 07-09-2019 \\ Corresponding Author: \\ Edoun Marcel \\ The U.I.T, P.O. Box 455 \\ University of Ngaoundere, \\ Cameroon \\ Email: edounmarcel@yahoo.fr
}

\begin{abstract}
In the current study, we developed and tested a new type of solar collector named $\mathrm{W}$-shape solar collector. It is a solar collector with single air pass between the transparent cover and the absorber. The cover has double glass whereby the upper glass is flat and the lower glass is wshape. The absorber is also W-shape. This combination gave rise to an undulatory airflow circulation in the new collector. This modular solar collector allowed the functioning of several configurations of flat plate solar thermal collector. After realization of the prototype, an experimental characterization was done during a natural period of sunshine in the town of Ngaoundere between November and December 2016. It consisted in characterizing the solar radiation, the input/output temperatures of the solar collector, the temperature of the absorber and the air velocity profile. During the experiments, the solar collector was directed facing the south and tilted either by $45^{\circ}$ or by $30^{\circ}$ compared to the horizontal plan. Temperature profile analysis showed at noon sun and air velocity of $0.3 \mathrm{~m} / \mathrm{s}$, the outlet air temperature of the $\mathrm{w}$-shape solar collector gives $75^{\circ} \mathrm{C}$ while that of the flat collector gives only $60^{\circ} \mathrm{C}$. Nevertheless, the temperature of the flat absorber was higher than that of the $\mathrm{W}$-shape absorber. This allowed us to conclude that the convection heat transfer coefficient of the $\mathrm{W}$-shape solar collector improved than the flat solar heat collector. Also the efficiency profiles highlight the positive contribution of the $\mathrm{W}$-shape in the improvement of the thermal performances of a solar collector.
\end{abstract}

Keywords: Solar Collector, W-Shape, Undulatory Airflow Circulation, Heat Transfer Coefficient

\section{Introduction}

Flat plate solar air heaters are simple in design and construction. He transforms solar radiation into thermal energy extracted by the fluid which circulated inside the collector. In agro-industries these collectors are frequently used in the field for drying, cooking or distillation process. These converters have a low convection heat transfer coefficient between the absorber plate and flowing air inside the collector. This is essentially due to the low thermo-physical properties of air (Amer et al., 2010). The performances of these systems can be improved, firstly, by optimizing the convective heat transfer coefficient between the plate absorber and the air, secondly, by reducing heat losses through the various components of the solar collector and thirdly by using artificial roughness and in various configurations to create turbulence airflow near wall.

Many solar collectors with porous absorbers (sheet steel spread in crushed stitch, crushed selective glass and liquid plastic foam) were designed and experimented (Rauzier, 1980; Olimat, 2017). Their efficiencies are $15 \%$ higher than the traditional collector (not porous sheet steel with passage of air between the sheet steel and the glass). Djomo in 1999 uses the combination of two materials to create the cover of the collector and shows that the efficiency on the new model reaches $45 \%$ with an outlet air temperature at $70^{\circ} \mathrm{C}$. In 2005 , a triple glass cover was introduced into plate solar collectors (Youcef-Ali, 2005). These works revealed that the collector with double-glass offers a thermal performance lower than that of the triple glass. In 2014, Ihaddadene et 
al., presented a study concerning the effect of distance between two glasses on the performance of a thermal solar collector. They concluded that the efficiency of the double-glass solar collector decreases with the increase of the distance separating both glasses. Comparative studies on single and double air pass inside the solar collector have been studied (Labed et al., 2009; Mahmood et al., 2015). The best efficiencies were observed in the case of double air pass. The influence of the position of the absorber inside the collector was also highlighted (Amer et al., 2010). The mix position of the absorber provided an outlet temperature with natural convection exceeding $98^{\circ} \mathrm{C}$ and in forced convection around $70^{\circ} \mathrm{C}$. The use of an inert gas (Argon, Xenon ...) instead of the air between the absorber and the glass cover permits the reduction of the heat losses to about 20 $\%$ (Vestlund et al., 2009).

To improve the convective heat transfer coefficient inside the solar collector, numerous researchers suggested firstly to increase the path traveled by heat transfer fluid in the collector and secondly the introduction of artificial roughness inside the airflow circulation (El-Sebaii et al., 2011; García et al., 2011; Visa et al., 2015; Han et al., 1985; Han et al., 1991; Lau et al., 1991; Gao and Sunder, 2001). Artificial roughness in form of fine wires (Prasad and Mullick, 1983), transverse small diameter wire as roughness element (Prasad and Saini, 1988), roughness height and angle of attack (Gupta et al., 1993) has been tested inside solar air heater. Momin et al. (2002) investigated effect of geometrical parameters of $\mathrm{V}$-shaped rib roughness and showed that the maximum thermo-hydraulic performance occurred for $60^{\circ}$. The effect of transverse, inclined, $\mathrm{V}$ continuous and $\mathrm{V}$ discrete pattern ribs on heat transfer enhancement was carried out by Karwa (2003). The result showed that Vdown arrangement gave best heat transfer performance. Han et al. (1991) studied square channel with V, parallel and crossed ribs. Results reported that $\mathrm{V}$-shaped rib performed better than parallel rib and also better than crossed rib. V-shaped rib produced highest heat transfer augmentation but generated greatest pressure drop. Crossed ribs produced lowest heat transfer enhancement and smallest pressure drop penalty. In summary, literature reveals that inclined and V-ribs give significant enhancement in heat transfer as compared to smooth plate. The artificial roughness contributed positively to the improvement of the thermal performances of solar collector but they produce a considerable pressure (Kabeel et al., 2016). Furthermore, the transparent cover whether it was for single, double or triple glass always remained flat. Most of the investigations carried out so far have applied artificial roughness or various forms on absorber and have not oriented the variation of the form of the solar collector cover.

Hence the present investigation has been taken up with objective of study a new form of solar collector cover: W-shaped cover. We have focused our attention on design and experimental characterization of the thermal performance of a new solar collector with a Wshape cover form.

\section{Materials and Methods}

\section{Description of Experimental Device \\ W-Shape Glass Model}

To contribute to the increase turbulence and the transfer coefficient between internal wall and the air, the second glass and the absorber were made in $\mathrm{W}$-shape form (Fig. 1). This form established obstacles to the current of air with consequence then creating an undulatory airflow.

\section{Experimental Instrument}

The measurements were made between February and April 2018 with the present solar collector. To evaluate global solar irradiation, air velocity, temperature and humidity, we used respectively a digital solar meter (Velleman DVM8090), an anemometer with helixes (Almemo FVAD 15S120 R1E4), six thermocouples (type K) and a hygrometer (Almemo ZAD936 RAK) recpectively. Every 30 minutes, by using the Almemo data acquisition, these parameters were automatically recorded (Almemo 2590). Three configurations can be tested using the new solar collector: Flat plate, semi $W$ shape and $W$-shape solar collector (Fig. 2).

\section{Evaluation of Thermal Performances}

To evaluate the thermal performances, the inlet air temperature is supposed to be equal to the ambient temperature and the absorber temperature is considered constant. The thermal power of collector is evaluated using Equation 1:

$Q_{u}=\dot{m} C_{p}\left(T_{s}-T_{e}\right)$

According to Eiamsa-ard and Promvonge (2006):

$Q_{u}=Q_{\text {conv }}$

If $Q_{\text {conv }}=h_{\text {cap }} S\left(T_{a b}-T_{f}\right)$

Thus, the heat transfer coefficient between the absorber and the air is given by Equation (4):

$h_{c o l}=\frac{Q_{u}}{A_{c}\left(T_{a b}-T_{f}\right)}$

The global solar irradiation $\mathrm{G}^{*}$ being determined through measurement, the global efficiency of solar collector is evaluated by application of Equation 5 (El-Sebaii et al., 2011): 
$\eta=\frac{\dot{m} C_{p}\left(T_{s}-T_{e}\right)}{A_{c} G^{*}}$

The lost pressure drops created by the geometry is calculated using the relation 6 :

$\Delta P=\frac{1}{2} C_{p} S_{p} L Q_{v}^{2}$

After evaluation of the lost pressure drop in the solar collector, the friction factor was determined by application of Equation 7 as describe by Li et al. (2017):

$$
f=\frac{\Delta P}{\frac{L}{D_{h}}\left(p \frac{v_{2}}{2}\right)}
$$

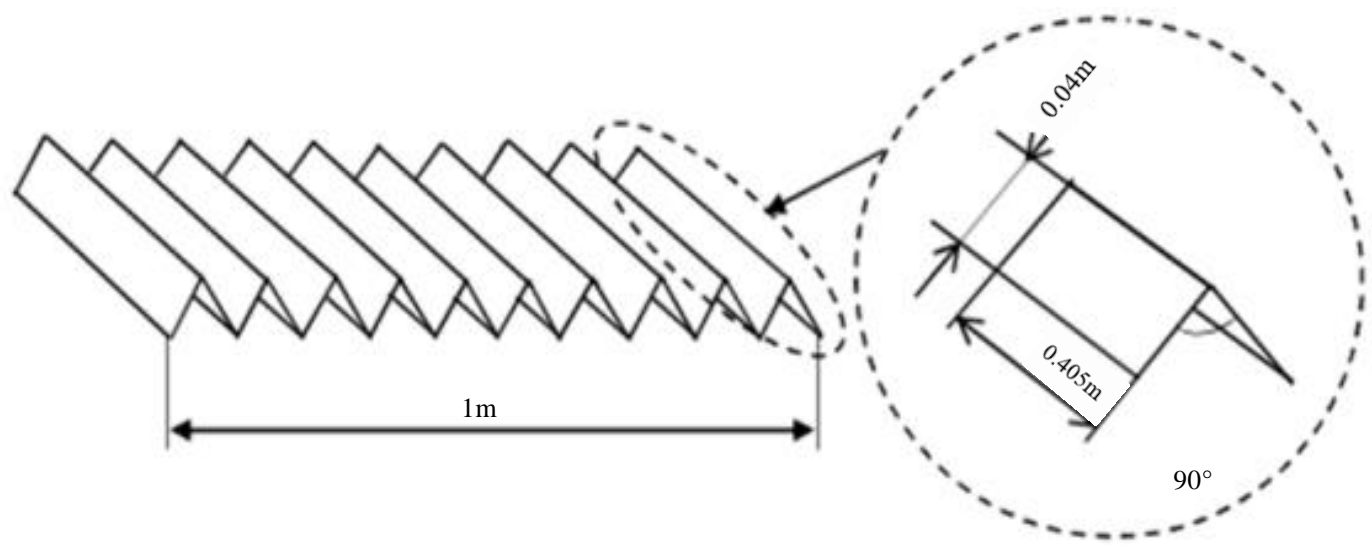

Fig. 1: Representation of the W-shape glass and the absorber form

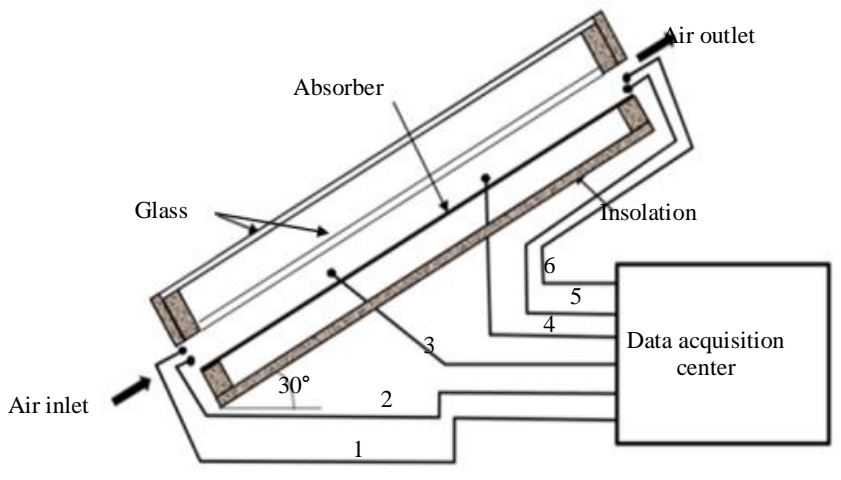

(a)

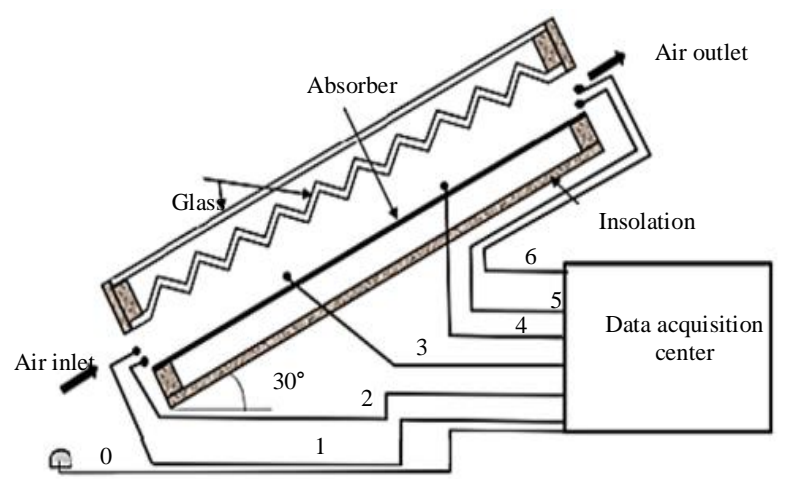

(b)

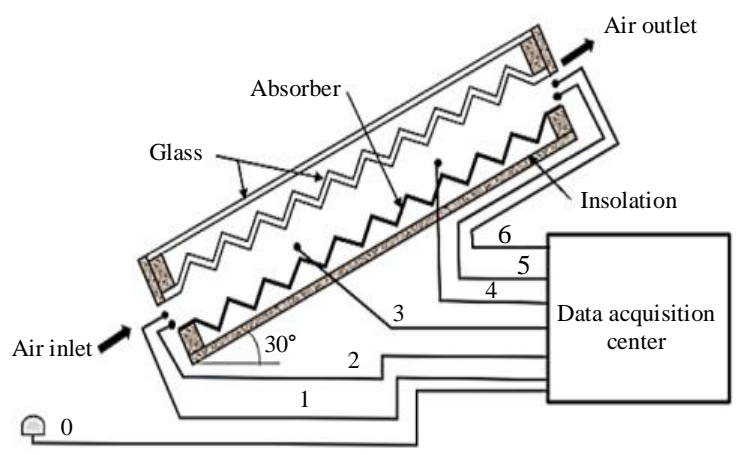

(c)

Fig. 2: Experimental device: (a) flat plate solar collector, (b) semi-W-shape solar collector, (c) W-shape solar collector; Legend: 0: Pyranometer; 1 and 6: Anemometer; 2: Hygrometer; 3, 4,5: Thermocouples 


\section{Results and Discussion}

\section{Representation of Prototype}

The prototype Fig. 3 was developed at the Laboratory Energetic and Applied Thermal process (LETA) of University of Ngaoundere. It consists of:

- A box made of local wood with a thickness of 15 $\mathrm{mm}$, dimensions of $1000 \times 450 \times 170 \mathrm{~mm}$, opened on the side exposed to solar radiation, on the lateral side, are openings for input and output of air

- A double glass whereby one of the cover has a flat surface $1000 \times 450 \mathrm{~mm}$ and the other cover grooved in the form of saw-shape which cover the housing and ensures the 'greenhouse effect' phenomenon

- An absorber (flat and grooved) made of black painted steel sheet which transmits heat to the coolant (air)

- Two holes of dimensions $150 \times 35 \mathrm{~mm}$ for the entry and exit of air

\section{Environmental Characteristics}

Evolution of solar irradiation as a function of time is represented in Fig. 4a. We observed that the two curves have a bell shape. This shows the increase and the decrease of sunlight during the day. Taking the theoretical curve as reference, we assumed that the experimental curve has an irregularity in its daily progress. This is due to the temporary covering of the sky. The solar flux evolves until 1076.4 W.m² for experimental studies and 1032.59 W.m ${ }^{2}$ for theoretical studies. The solar flux values proved the sufficiency of sunshine for the performance evolution of the solar collectors since the American Society of Heating, Refrigerating and Air-Conditioning Engineers standard (ASHRAE) standard requires that, for the solar collector efficacy test, solar radiation must be above $630 \mathrm{~W} / \mathrm{m}^{2}$ (Abene et al., 2004). Figure 4b shows the evolution of global irradiance at ambient temperature and soil temperature during testing. The ambient temperature increase with sunlight. The average ambient temperature was $36^{\circ} \mathrm{C}$. The Fig $4 \mathrm{c}$ represents the evolution of relative humidity and air velocity at the inlet collector. Under normal conditions, the air velocity is random. As for relative humidity, it decreases with an increase of sunlight.

\section{Influence of Collector's Configuration on the Temperature Profiles}

The curves relating to the evolution of the air temperature at the inlet and outlet of the collector for the three configurations studied are shown in Fig. 5. The gap temperature between the inlet and the outlet is of the order of $25^{\circ} \mathrm{C}$ for the flat collector; $30^{\circ} \mathrm{C}$ for the semi $\mathrm{W}$-shape collector and $35^{\circ} \mathrm{C}$ for the $\mathrm{W}$-shape collector. Whatever the configuration, there is a considerable difference between the inlet and output temperature. This gap is also a function of the amplitude of the sunshine. However, the highest output temperature collectors were recorded for $\mathrm{W}$-shape solar collector with a maximum of about $77.7^{\circ} \mathrm{C}$ at 12 o'clock (local time). This result could be explained by the increase of the time of air resident in the w-shape collector and on the other hand by the increase in the convective thermal exchange coefficient caused by W-shape geometry. These results are similar with those of literature (El-Sebaii et al., 2011; García et al., 2011; Handoyo et al., 2016) which show that the presence of baffles in the air stream improves the thermal performance of an air solar collector.

\section{Influence of Solar Configuration on Useful Power}

For the three types of solar collectors studied, the experimental results made it possible to evaluate the useful power recovered by the air (Fig. 6). The highest values were obtained with the $\mathrm{W}$-shape collector (average $70 \mathrm{~W}$ ). This is logical because, for this configuration, the gap between the temperature of the air and that of the absorber is important compared to the two others.

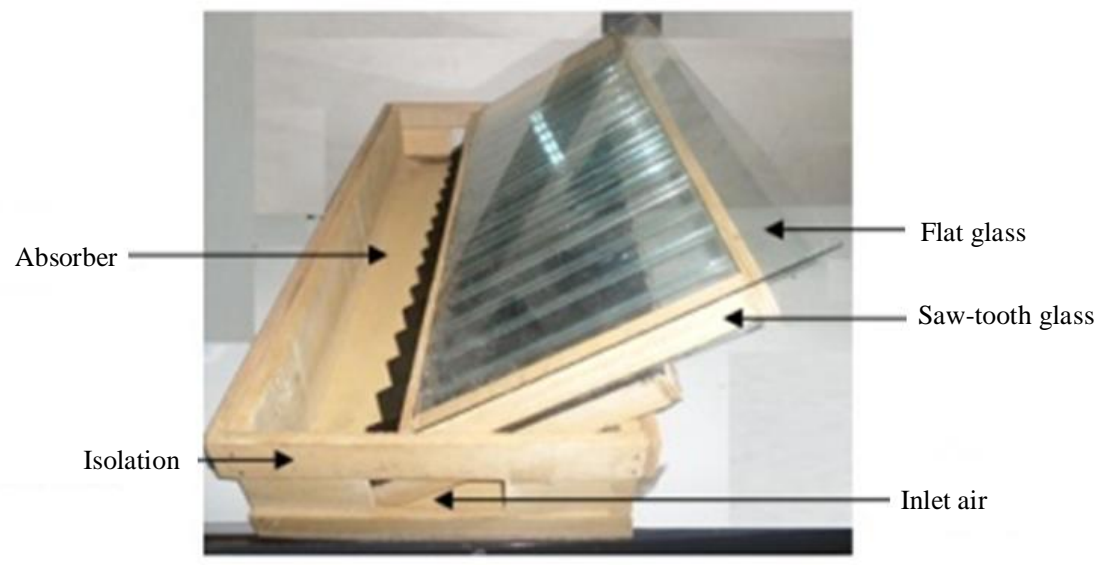

(a) 
Edoun Marcel et al. / American Journal of Engineering and Applied Sciences 2019, 12 (3): 440.449 DOI: 10.3844/ajeassp.2019.440.449

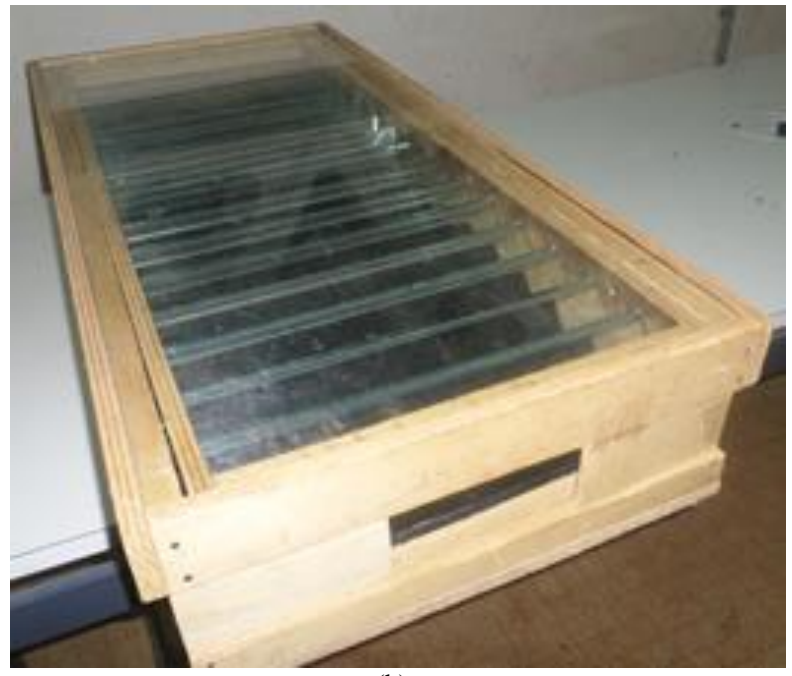

(b)

Fig. 3: W-shape solar collector; (a) detailed and annotated view; (b) Overview
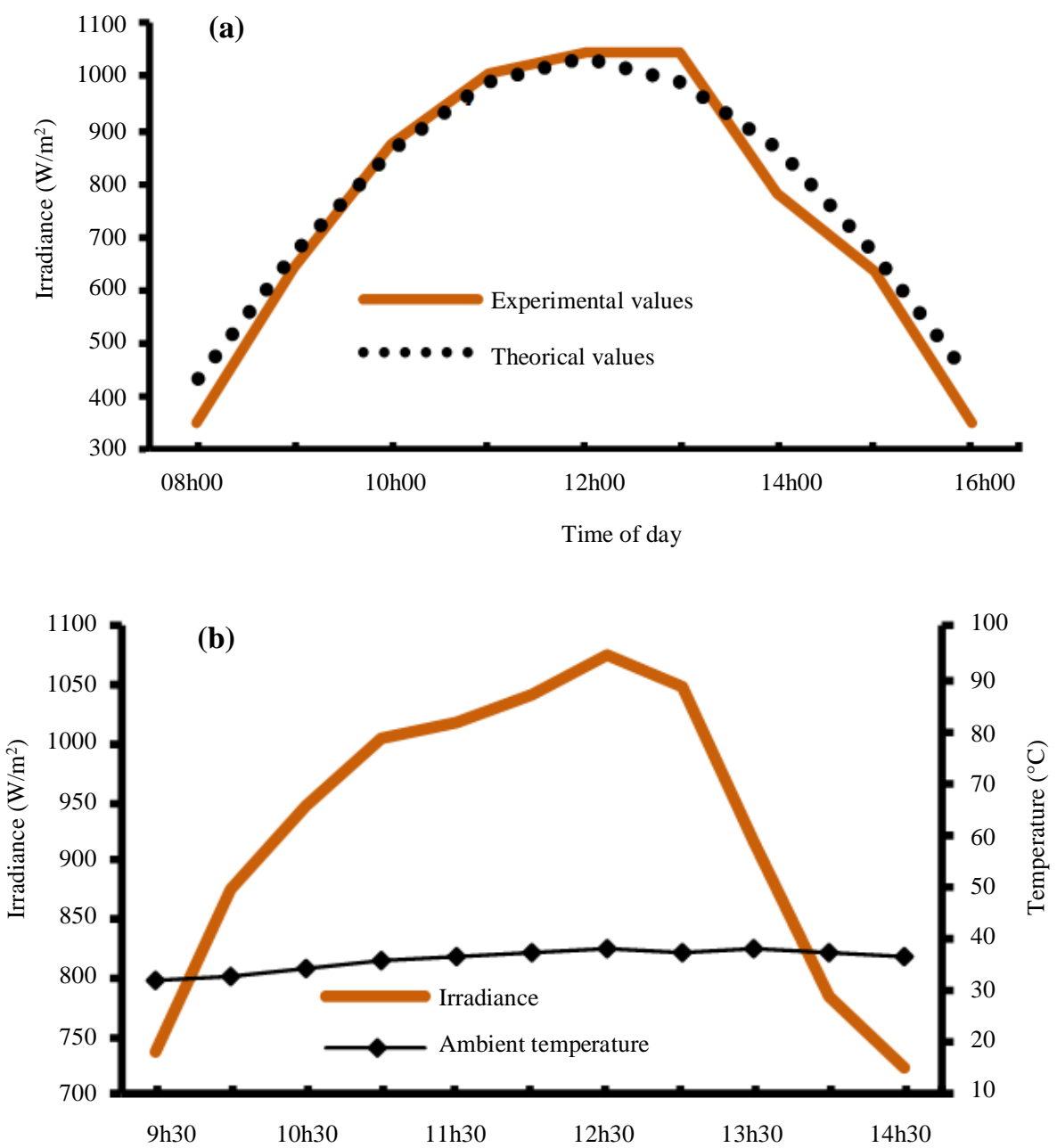

Time of day 


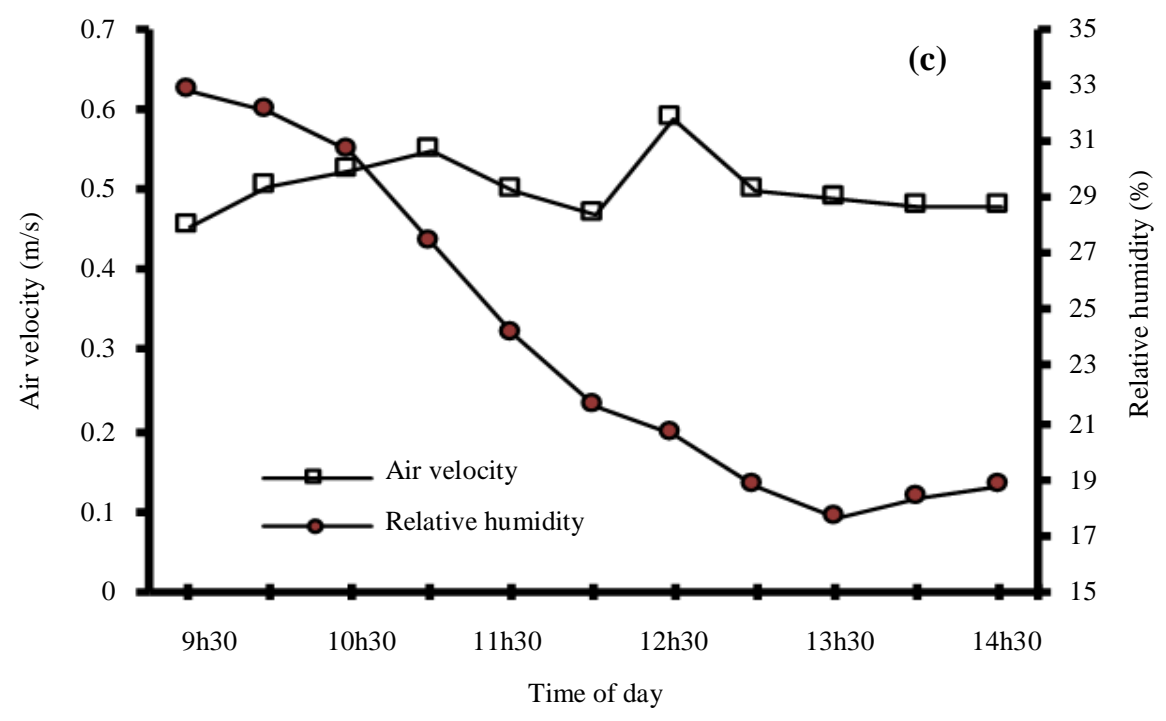

Fig. 4: Evolution of climatic parameters based on period of day

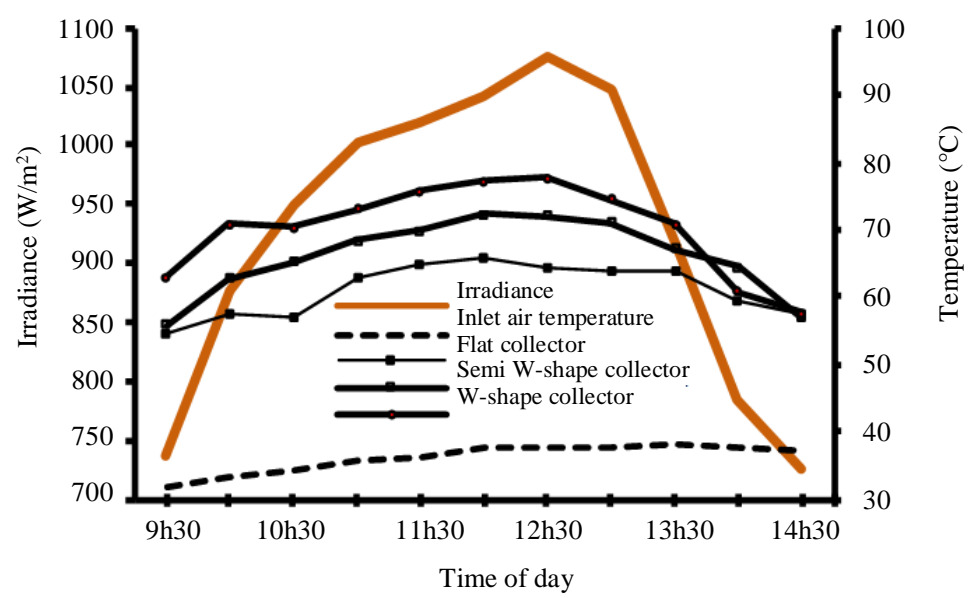

Fig. 5: Evolution of irradiance and inlet/outlet air temperature of solar collector

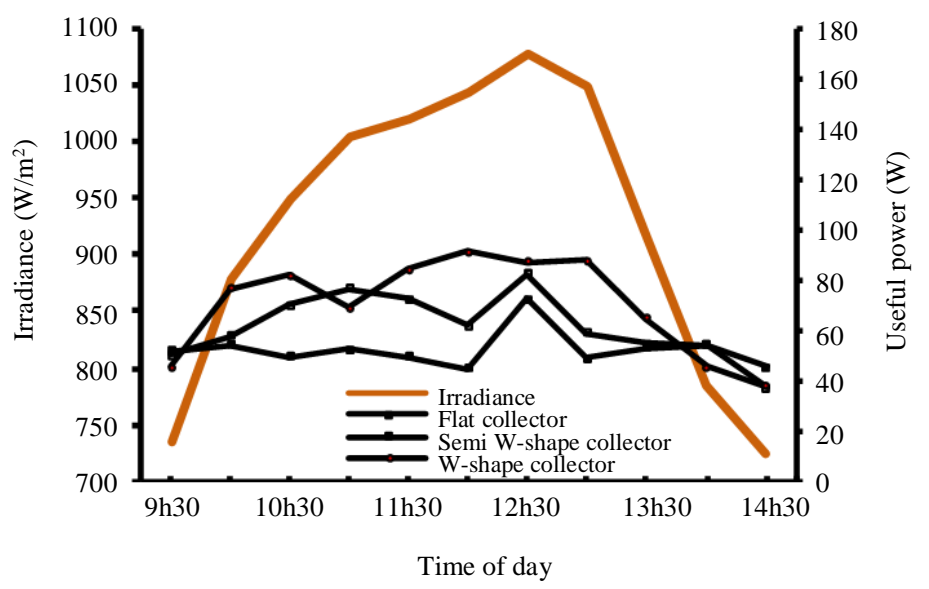

Fig. 6: Evolution of irradiance and useful power per period of the day 


\section{Influence of Configurations on Air/Absorber Thermal Exchange Coefficient}

Figure 7 shows the evolution of heat exchange coefficient of the flat plate, semi $\mathrm{W}$-shape and $\mathrm{W}$-shape solar collector. It appeared from the analysis of the curves that the semiW-shape and $\mathrm{W}$-shape solar collector had the highest average thermal exchange coefficient (respectively $5.71 \mathrm{~W} \cdot \mathrm{m}^{-2} \cdot{ }^{\circ} \mathrm{C}^{-1}$ and $7.2 \mathrm{~W} \cdot \mathrm{m}^{-2} .{ }^{\circ} \mathrm{C}^{-1}$ ). But that of the flat collector was weak and equal to 4.11 $\mathrm{W} \cdot \mathrm{m}^{-2} \cdot{ }^{\circ} \mathrm{C}^{-1}$. These results proved that there was a clear improvement in heat exchange in the collector by Wshape geometry.

\section{Influence of Configurations on the Instantaneous Global Efficiency}

Figure 8 shows evolution of instantaneous global efficiency based on configuration. From the analysis of the curves of this figure, it is noted that the overall efficiency is around $14 \%$ for the planar collector, $17 \%$ for the semi Wshape and $22 \%$ for the $\mathrm{W}$-shape solar collector. The Wshape solar collector shows an improvement in efficiency of $8 \%$ compared to the efficiency of the flat solar collector. This is explained by the fact that the W-shape absorber and
W-shape glass cover has a larger exchange surface and a long fluid circulation.

\section{Influence of Configurations on Pressure Drop and Friction Factor}

Figure 9 represents the profiles of pressure drops in the collector. The analysis of the different profiles showed that the semi W-shape and W-shape collector generated more pressure drops. This is due to the Wshape geometry which brought roughness in the airstream. On the three configurations studied, the Wshape solar collector with a grooved window and absorber generated more heat losses compared to the semi W-shape collector. These losses were approximately 287 $\mathrm{Pa}, 630 \mathrm{~Pa}$ and $690 \mathrm{~Pa}$ respectively for flat plate, for semi $\mathrm{W}$-shape and $\mathrm{W}$-shape solar collector. The results coincided with that of literature which stated that the presence of obstacles generated pressure drops and caused high pumping power (Visa et al., 2015; Kabeel et al., 2016; Kewou et al., 2018; Benli, 2013).

Considering these losses generated in the collector, the evolution of friction factor gave a result of 78 for the flat solar collector, 178 for the semi W-shape solar collector and 198 for the W-shape solar collector.

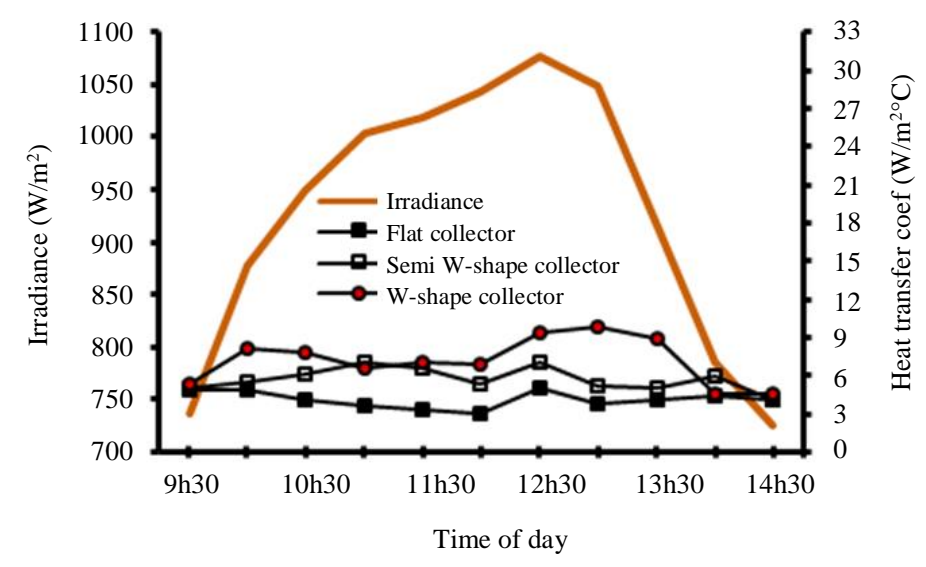

Fig. 7: Evolution of irradiance and air/absorber thermal exchange coefficient with respect to time

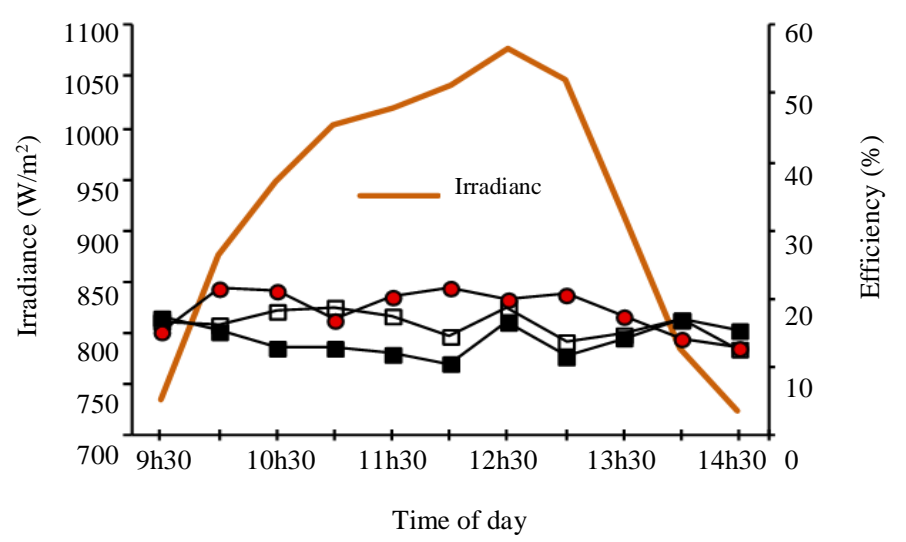

Fig. 8: Evolution of irradiance and instantaneous efficiency with respect to time 


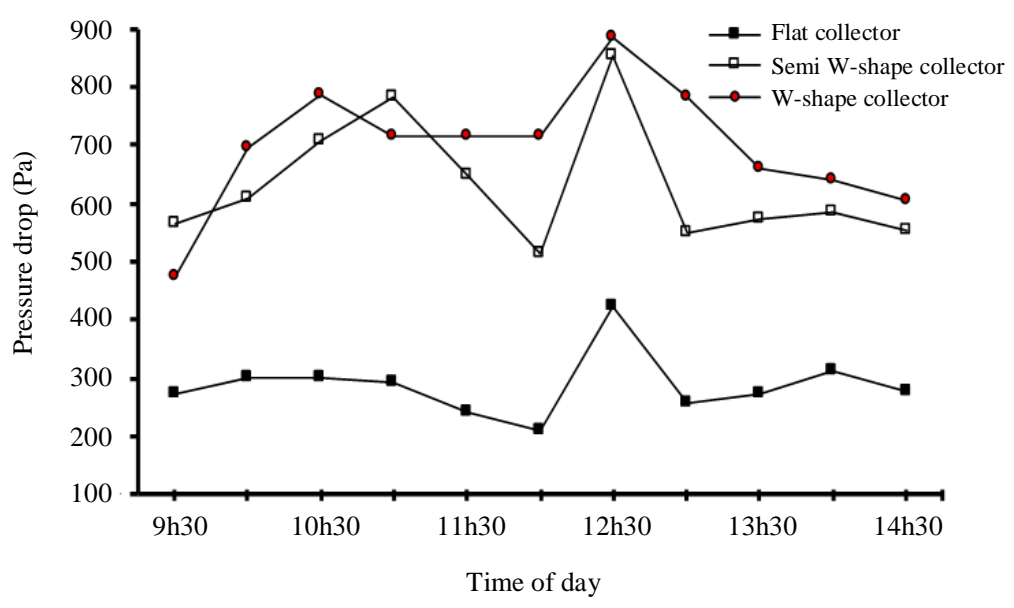

Fig. 9: Evolution of pressure drop as function of time for the tree configurations

\section{Conclusion}

The W-shape solar collector was designed and tested in ENSAI Laboratory of Energetic and Applied thermal process. It is a modular solar collector with double-glass cover. Experimental revealed positive influence of the geometry of the cover and absorber on the thermal performance of a collector. It appears that $\mathrm{W}$-shape solar collector is profitable; during natural convection outlet temperature of up to $77.7^{\circ} \mathrm{C}$, an overall efficiency of up to $22 \%$ and an average heat exchange coefficient between air and absorber of approximately 7.20 $\mathrm{W} / \mathrm{m}^{2}{ }^{\circ} \mathrm{C}$ higher than that of the flat solar collector $(4.11$ $\left.\mathrm{W} / \mathrm{m}^{2} .{ }^{\circ} \mathrm{C}\right)$. But the semi $\mathrm{W}$-shape and $\mathrm{W}$-shape collector generated more pressure drops. This suggests that the presence of $\mathrm{W}$-shape cover and $\mathrm{W}$-shape absorber improved heat exchange in the thermal solar collector.

\section{Author Contributions}

Edoun Marcel: Designed the solar collector, performed the experiments and wrote the paper.

Djimasra Bonheur: Did the experiments and wrote the paper.

Kuitche Alexis and Zeghmati Belkacem: Performed the experiments and corrected the paper.

\section{Ethics}

This article is original. The corresponding author confirms that all of the other authors have read and approved the manuscript and no ethical issues involved.

\section{References}

Abene, A.V.D., M. Le Ray and A. Ouagued, 2004. Study of a solar air flat plate collector: Use of obstacles and application for the drying of grape. J. Food Eng., 65: 15-22. DOI: 10.1016/j.jfoodeng.2003.11.002
Amer, B.M.A. and M.A. Hossain and K.Gottschalk, 2010. Design and performance evaluation of a new hybrid solar dryer for banana. Energy Conv. Manag., 51: 813-820. DOI: 10.1016/j.enconman.2009.11.016

Benli, H., 2013. Experimentally derived efficiency and exergy analysis of a new solar air heater having different surface shapes, Ren. Energy, 50:58-67. DOI: $10.1016 /$ j.renene.2012.06.022

Eiamsa-ard, S. and P. Promvonge, 2006. Experimental investigation of heat transfer and friction characteristics in a circular tube fitted with V-nozzle turbulators. Int. Com. Heat Mass Trans., 33: 591-600. DOI: 10.1016/j.icheatmasstransfer.2006.02.022

El-Sebaii, A.A., S. Aboul-Enein, M.R.I. Ramadan, S.M. Shalaby and B.M. Moharram, 2011. Investigation of thermal performance of-double pass-flat and vcorrugated plate solar air heaters. Energy, 36: 10761086. DOI: 10.1016/j.energy.2010.11.042

Gao, X. and B. Sunden, 2001. Heat transfer and pressure drop measurements in rib roughened rectangular ducts. Exp. Fluid Sci., 24: 25-34. DOI: 10.1016/s0894-1777(00)00054-6

García, A., J.P. Solano, P.G. Vicente and A. Viedma, 2012. The influence of artificial roughness shape on heat transfer enhancement: Corrugated tubes, dimpled tubes and wire coils. Applied Eng., 35:196-201. DOI: 10.1016/j.applthermaleng.2011.10.030

Gupta, D., S.C. Solanki and J.S. Saini, 1993. Heat and fluid flow in rectangular solar air heater ducts having transverse rib roughness on absorber plates. Solar Energy, 51: 31-37. DOI: 10.1016/0038-092x(93)90039-q

Han, J.C., J.S. Park and C.K. Lei, 1985. Heat transfer enhancement in channels with turbulence promoters. J. Eng. Gas Turbines Power, 107: 628-635. DOI: $10.1115 / 1.3239782$ 
Han, J.C., Y.M. Zhang and C.P. Lee, 1991. Augmented heat transfer in square channels with parallel, crossed and V-shaped angled ribs. J. Heat Trans., 113: 590-596.

Handoyo, E.A., D.I. Prabowo and Sutardi, 2016. Numerical studies on the effect of delta-shaped obstacles' spacing on the heat transfer and pressure drop in v-corrugated channel of solar air heater. Solar Energy, 131: 47-60. DOI: 10.1016/j.solener.2016.02.031

Ihaddadene, N., R. Ihaddadene and A. Mahdi, 2014. Effect of Distance between Double Glazing on the Performance of a Solar Thermal Collector. Ren. Energy Power Qual. J., 12: 302-306. DOI: $10.24084 /$ repqj12.318

Kabeel, A.E., A.Khalil, S.M. Shalaby and M.E. Zayed, 2016. Experimental investigation of thermal performance of flat and v-corrugated plate solar air heaters with and without PCM as thermal energy storage., Energy Conv. Manage., 113: 264-272. DOI: 10.1016/j.enconman.2016.01.068

Karwa, R., 2003. Experimental studies of augmented heat transfer and friction in asymmetrically heated rectangular ducts with ribs on the heated wall in transverse, inclined, V-continuous and V-discrete pattern. Int. Com. Heat Mass Trans., 30: 241-250. DOI: 10.1016/s0735-1933(03)00035-6

Kewou, S., M. Edoun, O.M. Tawetsing and A. Kuitche 2018. Numerical simulation of convective heat transfer coefficient in channel with corrugated walls. Thermal Sci., 22: 87-100. DOI: 10.2298/tsci150615061k

Labed, A., N. Moummi, A. Benchabane, K. Aoues and Moummi, 2009. Performance investigation of single A. - and double-pass solar air heaters through the use of various fin geometries. Int. J. Sust. Energy, 31: 423-434. DOI: 10.1080/14786451.2011.649837

Lau, S.C., R.D. Mcmillin and J.C. Han, 1991. Heat transfer characteristics of turbulent flow in a square channel with angled discrete ribs. J. Turb., 113: 367-374. DOI: 10.1115/1.2927885

Li, S., H. Wang, X. Meng and X. Wei, 2017. Comparative study on the performance of a new solar air collector with different surface shapes. Applied Eng., 114: 639-644.

DOI: $10.1016 /$ j.applthermaleng.2016.12.026
Mahmood, A.J., L.B.Y. Aldabbagh and F. Egelioglu, 2015. Investigation of single and double pass solar air heater with transverse fins and a package wire mesh layer. Energy Conv. Manage., 89: 599-607. DOI: 10.1016/j.enconman.2014.10.028

Momin, A.M.E., J.S. Saini and S.C. Solanki, 2002. Heat transfer and friction in solar air heater duct with V-shaped rib roughness on absorber plate, Int. J. Heat Mass Trans., 45: 3383-3396. DOI: $10.1016 / \mathrm{s} 0017-9310(02) 00046-7$

Njomo, D., 1998. Theoretical study of a plane solar collector with plastic-glass combined cover. Rev. Gen., 37: 973-980.

DOI: $10.1016 / \mathrm{s} 0035-3159(98) 80022-6$

Olimat, A.N., 2017. Study of fabricated solar dryer of tomato slices under Jordan climate condition. Int J. Ren. Energy Develop., 6: 93-101. DOI: 10.14710/ijred.6.2.93-101

Prasad, B.N. and J.S. Saini, 1988. Effect of artificial roughness on heat transfer and friction factor in a solar air heater. Solar Energy, 41: 555-560. DOI: 10.1016/0038-092x(88)90058-8

Prasad, K. and S.C. Mullick, 1983. Heat transfer characteristics of a solar air heater used for drying purposes. Applied Energy, 13: 83-93. DOI: 10.1016/0306-2619(83)90001-6

Rauzier, E. 1980. Expérimentation de capteurs solaires à air à absorbeur poreux. Rev. Phys. Applied, 15: 411-415. DOI: 10.1051/rphysap:01980001503041100

Vestlund, J., M. Rönnelid and J. Dalenbck, 2009. Thermal performance of gas-filled flat plate solar collectors. Solar Energy, 83: 896-904.

DOI: 10.1016/j.solener.2008.12.005

Visa, I., A. Duta, M. Comsit, M. Moldovan and D. Ciobanuet al., 2015. Design and experimental optimization of a novel flat plate solar thermal collector with trapezoidal shape for facades integration. Applied Thermal Eng., 90: 432-443. DOI: 10.1016/j.applthermaleng.2015.06.026

Youcef-Ali, S., 2005. Study and optimization of the thermal performances of the offset rectangular plate fin absorber plates, with various glazing. Ren. Energy, 30: 271-280. DOI: 10.1016/j.renene.2004.04.009

\section{Nomenclature}

\begin{tabular}{ll}
\hline$A_{c}$ & Surface of flat collector $\left(\mathrm{m}^{2}\right)$ \\
$C_{p}$ & Specific heat capacity of air $\left(\mathrm{J} / \mathrm{kg}^{\circ} \mathrm{C}\right)$ \\
$D_{h}$ & Hydraulic diameter $(\mathrm{m})$ \\
$f$ & Friction Factor \\
$G^{*}$ & Global flux received by the collector $\left(\mathrm{W} / \mathrm{m}^{2}\right)$ \\
$h_{c o l}$ & Internal thermal exchange coefficient of collector $\left(\mathrm{W} / \mathrm{m}^{2 \circ} \mathrm{C}\right)$ \\
$H R$ & Relative Humidity $(\%)$ \\
$L$ & Lenght of collector $(\mathrm{m})$ \\
$\dot{m}$ & Mass air flow $(\mathrm{kg} / \mathrm{s})$ \\
$Q_{c o n v}$ & Thermal flux exchanged between air and absorber $(\mathrm{W})$ \\
\hline
\end{tabular}


Edoun Marcel et al. / American Journal of Engineering and Applied Sciences 2019, 12 (3): 440.449 DOI: 10.3844/ajeassp.2019.440.449

\begin{tabular}{l}
\hline$Q_{u}$ \\
$Q_{v}$ \\
$S$ \\
$T_{a b}$ \\
$T_{a m b}$ \\
$T_{e}$ \\
$T_{f}$ \\
$T_{s}$ \\
$V$ \\
$\Delta P$ \\
$\rho$ \\
$\eta$
\end{tabular}
Thermal Air power $(\mathrm{W})$

Flow volume of air $\left(\mathrm{m}^{3} / \mathrm{s}\right)$

Inlet/outlet section of collector $\left(\mathrm{m}^{2}\right)$

Absorber temperature $\left({ }^{\circ} \mathrm{C}\right)$

Ambient Temperature $\left({ }^{\circ} \mathrm{C}\right)$

inlet collector temperature $\left({ }^{\circ} \mathrm{C}\right)$

Average air temperature $\left({ }^{\circ} \mathrm{C}\right)$

Outlet collector temperature $\left({ }^{\circ} \mathrm{C}\right)$

Air velocity $(\mathrm{m} / \mathrm{s})$

Pressure drops $(\mathrm{Pa})$

Volumic mass $\left(\mathrm{kg} / \mathrm{m}^{3}\right)$

Efficiency of the collector (\%) 